\title{
PEGEMBANGAN GAME DENGAN MENGGUNAKAN TEKNOLOGI VOICE RECOGNITION BERBASIS ANDROID
}

\author{
Franky Hadinata Marpaung; Rhio Sutoyo; Daniel; Yonas; Vedro \\ Information Systems Department, School of Information Systems, Binus University \\ Jl. K.H. Syahdan No. 9, Palmerah, Jakarta Barat 11480 \\ fmarpaung@binus.edu, rsutoyo@binus.edu,
}

\begin{abstract}
The purpose of this research is to create a new kind of game by using technology that rarely used in current games. It is developed as an entertainment media and also a social media in which the users can play the games together via multiplayer mode. This research uses Scrum development method since it supports small scaled developer and it supports software increment along the development. Using this game application, the users can play and watch interesting animations by controlling it with their voice, listen the character imitating the users' voice, play various mini games both in single player or multiplayer mode via Bluetooth connection. The conclusion is that game application of My Name is Dug use voice recognition and inter-devices connection as its main features. It also has various mini games that support both single player and multiplayer.
\end{abstract}

Keywords: game, voice, recognition, android

\begin{abstract}
ABSTRAK
Tujuan dari penelitian adalah untuk menciptakan suatu permainan yang lebih baru dengan menggunakan teknologi yang jarang digunakan dalam game-game yang telah ada. Game ini juga bertujuan sebagai media hiburan dan media sosialisasi dengan para pemain dapat bermain bersama melalui multi-player game. Penelitian ini menggunakan metode penelitian Scrum karena cocok bagi tim pengembang yang kecil dan memungkinkan untuk software increment selama pengembangan. Dengan menggunakan aplikasi game ini, para pengguna dapat bermain dan melihat animasi-animasi menarik dengan mengontrolnya lewat suara mereka, mendengar sang karakter meniru suara penggunanya, dan bermain berbagai mini games baik sendiri maupun berdua melalui koneksi Bluetooth. Kesimpulan dari penelitian ini adalah aplikasi game My Name is Dug menggunakan teknologi voice recognition dan inter-devices connection sebagai fitur utamanya. Aplikasi game My Name is Dug juga memiliki minigames yang mendukung baik single player maupun multiplayer.
\end{abstract}

Kata kunci: game, suara, mengenali, android 


\section{PENDAHULUAN}

Kata game memang sudah tidak asing bagi setiap orang, baik dari kalangan anak-anak maupun dewasa. Dapat diakui bahwa saat ini keberadaan game sudah menjadi salah satu kebutuhan dalam kehidupan. Game dapat dijadikan sarana rekreasi atau hiburan, bahkan bagi beberapa orang, game menjadi suatu bidang pekerjaan.

Perangkat yang digunakan untuk bermain game sangat bermacam-macam. Ada game yang menggunakan console seperti Nintendo Wii, atau game yang menggunakan komputer yang biasa disebut PC Games, dan ada juga game yang dimainkan di mobile phone dan tablet PC. Game yang ada pada mobile phone dan tablet $P C$ sendiri memiliki kelebihan, salah satunya bersifat portable. Selain itu, harus diakui bahwa harga game yang dijual pada mobile phone dan tablet $P C$ relatif murah bahkan terkadang gratis.

Pada mobile phone dan tablet PC, sistem operasi yang digunakan bermacam-macam seperti Symbian, Windows, Macintosh (iOS), Blackberry, dan Android. Tetapi beberapa tahun terakhir ini, Macintosh, Blackberry, dan Android menjadi yang paling populer. Berikut ini adalah perbandingan antara Blackberry, Macintosh, dan Android dilihat dari beberapa fitur yang tersedia.

Tabel 1 Perbandingan fitur Sistem Operasi Blackberry, Macintosh, dan Android di akhir tahun 2011

\begin{tabular}{l|lll}
\hline \multicolumn{1}{l}{ Device } & Blackberry & iOS & Android \\
\cline { 2 - 4 } $\begin{array}{l}\text { Chatting and } \\
\text { Social Networking }\end{array}$ & Blackberry & iPad, iPhone, iPod Touch, etc. & Samsung, HTC, etc. \\
Touch Screen & $\begin{array}{l}\text { Available } \\
\text { Available in some } \\
\text { Blackberry phone type such } \\
\text { as BB Torch. }\end{array}$ & $\begin{array}{l}\text { Available in all Apple products } \\
\text { with iOS }\end{array}$ & $\begin{array}{l}\text { Available in most of } \\
\text { products with Android OS }\end{array}$ \\
$\begin{array}{l}\text { Voice and Motion } \\
\text { Sensor System }\end{array}$ & Not Available & Available & Available \\
Lowest Price & \pm IDR 2,000,000 & \pm IDR 3,000,000 & \pm IDR 1,500,000 \\
\hline
\end{tabular}

Dari tabel di atas dapat disimpulkan bahwa sistem operasi Macintosh dan Android lebih unggul dibandingkan dengan Blackberry, karena pada sistem operasi Blackberry tidak terdapat sistem sensor suara dan gerak. Selain Blackberry, jika dibandingkan dengan Macintosh, harga yang ditawarkan oleh Android relatif lebih murah sehingga Android lebih banyak dipakai. Hal ini juga dapat dilihat dari tabel market share mobile phone pada tahun 2010, 2011, dan perkiraan untuk tahun 2012 dan 2015 berikut ini. 
Tabel 2 Market Share Mobile Phone pada Berbagai Sistem Operasi (Sumber: Gartner, 2011)

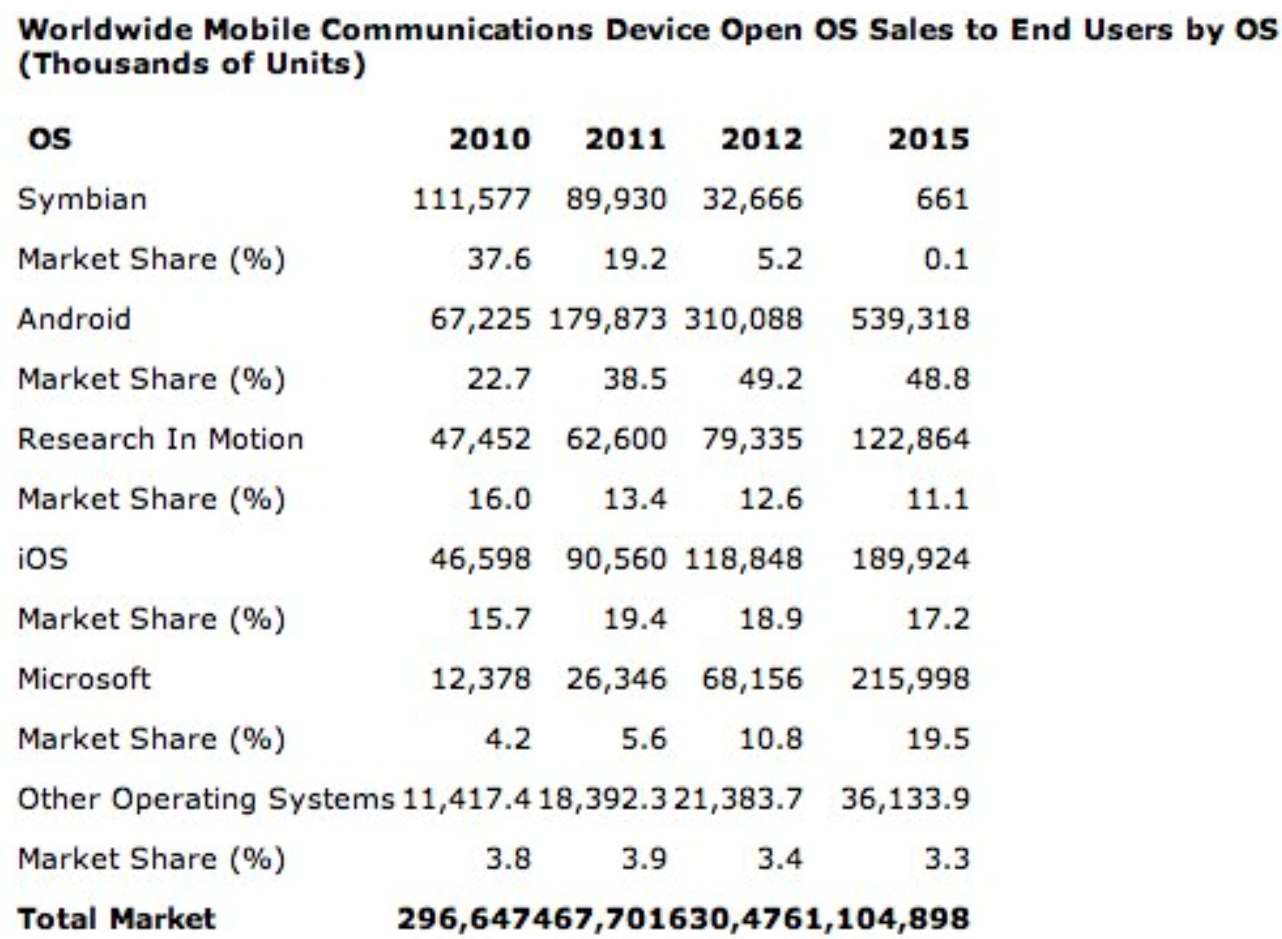

Source: Gartner (April 2011)

Dengan sistem operasi yang ada, mobile phone mampu memiliki teknologi-teknologi yang menunjang kehebatan suatu game. Game yang sekarang ada pada mobile phone banyak yang menggunakan teknologi motion detection, sehingga user dapat mengontrol permainan dengan menggerakkan mobile phone. Selain motion detection, masih banyak teknologi pada mobile phone yang dapat dikembangkan untuk menjadi game yang menarik, beberapa diantaranya adalah voice recognition dan inter-devices connection (Desai and Colaco, 2010).

Dengan voice recognition, game akan lebih menarik karena user dapat mengontrol permainan dengan suara. Inilah yang akan membuat suatu game menjadi lebih unik dibandingkan dengan yang lain. Dan jika dibandingkan dengan PC game, pengembangan game pada mobile phone menggunakan sistem multi player relatif kurang. Jika multi player game pada PC (DOTA, Ragnarok, dan sebagainya.) sukses dan banyak peminatnya, maka implementasi sistem multi player pada mobile phone patut diperhitungkan. Sistem ini dapat diimplementasikan dengan menghubungkan masingmasing mobile phone, salah satunya dengan Bluetooth.

Saat ini banyak sekali jenis aplikasi game yang ada. Salah satu contohnya Talking Tom Cat. Pada aplikasi game ini user dapat bermain bersama seekor kucing yang akan meniru setiap suara user. Aplikasi game ini bersifat lucu dan menyenangkan sehingga dapat diterima oleh semua orang. Tetapi masih ada beberapa hal yang belum dikembangkan lebih dalam oleh aplikasi game Talking Tom Cat tersebut, yaitu dalam hal voice recognition dan inter-devices connection menggunakan teknologi Bluetooth. Oleh karena itu, pernyataan tersebut menjadi latar belakang penelitian ini. 


\section{METODE PENELITIAN}

Pengumpulan data dan informasi dilakukan dengan menggunakan teknik fact finding method, antara lain : (1) Studi Pustaka; merupakan teknik pengumpulan data atau informasi yang berbentuk literatur berupa buku, jurnal, maupun e-book yang berkaitan dengan teori- teori mobile phone application, pemrograman pada Java yang dibuat untuk sistem operasi Android, dan cara membuat suatu voice recognition dan inter-devices connection menggunakan koneksi bluetooth. (2) Observasi; dilakukan untuk mengetahui keadaan lapangan, dalam hal ini yaitu mencari informasi untuk mengetahui berbagai perilaku dan sifat anjing pada umumnya. (3) Kuesioner; dilakukan untuk mengetahui data mobile phone yang digunakan, fitur, serta permintaan pasar yang ada. Selain itu, kuesioner juga digunakan untuk mengevaluasi aplikasi game yang sudah dibuat.

Metode yang digunakan dalam perancangan game ini adalah metode Scrum yang merupakan bagian dari Agile Development. Metode Scrum lebih cocok diterapkan pada perancangan game ini dibandingkan dengan metode lainnya seperti metode waterfall. Metode waterfall tidak begitu efektif karena tim pengembang sulit untuk melakukan perubahan selama pengembangan. Sebagai tambahan, tim pengembang akan mengulang langkah-langkah sebelumnya lagi saat menemukan masalah dalam pengujian game. Hal tersebut akan menyebabkan kerugian dalam hal waktu dan biaya.

Sebaliknya, dengan metode Scrum, tim pengembang tidak diharuskan mengulang semua langkah-langkah sebelumnya. Jika tim pengembang harus melakukan perubahan, mereka bisa melakukannya pada saat melakukan sprint. Selain itu, metode Scrum cocok diterapkan pada perancangan game karena mengandalkan ukuran tim yang kecil sehingga pekerjaan masing-masing menjadi spesifik, efektif, dan efisien. Tim perancang hanya akan berfokus kepada feature yang telah ditetapkan sehingga proyek tidak akan keluar dari jalur. Metode ini juga dapat beradaptasi terhadap perubahan teknis, dapat menghasilkan software increment, serta pengujian yang dilakukan terus menerus selama pengembangan game.

Berdasarkan Keith (2010), aktivitas pada metode Scrum adalah: (1) Backlog; pada aktivitas backlog, didaftarkan kebutuhan-kebutuhan apa saja yang diperlukan untuk mengembangkan game ini. Hal ini disebut dengan product backlog. Daftar kebutuhan ini dapat bertambah seiring perancangan game. Lalu product backlog dibagi menjadi tugas-tugas yang lebih spesifik yang disebut dengan sprint backlog. Sebagai contoh tim pengembang melakukan rapat untuk mendaftar fitur-fitur dan apa saja yang diperlukan dalam game yang ingin dikembangkan. (2) Sprint; unit pekerjaan yang diperlukan untuk memenuhi kebutuhan yang telah ditetapkan dalam backlog sesuai dengan waktu yang ditetapkan. Selama proses ini berlangsung backlog tidak ada penambahan. Sebagai contoh tim pengembang dibagi menjadi kelompok yang lebih kecil lagi untuk melakukan tugas secara spesifik. (3) Daily Scrum Meeting; pertemuan singkat setiap harinya dilakukan untuk mengevaluasi apa yang telah dikerjakan dan hambatan yang ada selama satu sprint. Pada pertemuan ini juga ditetapkan target penyelesaian untuk bahan pertemuan selanjutnya. Sebagai contoh tim pengembang melakukan rapat rutin untuk menggabungkan bagiannya masing-masing dan mengevaluasinya.

Penyerahan dan pengujian game (software increment) untuk dievaluasi lebih lanjut. Sebagai contoh tim pengembang memberikan demo kepada para ahli untuk diuji serta dievaluasi. 


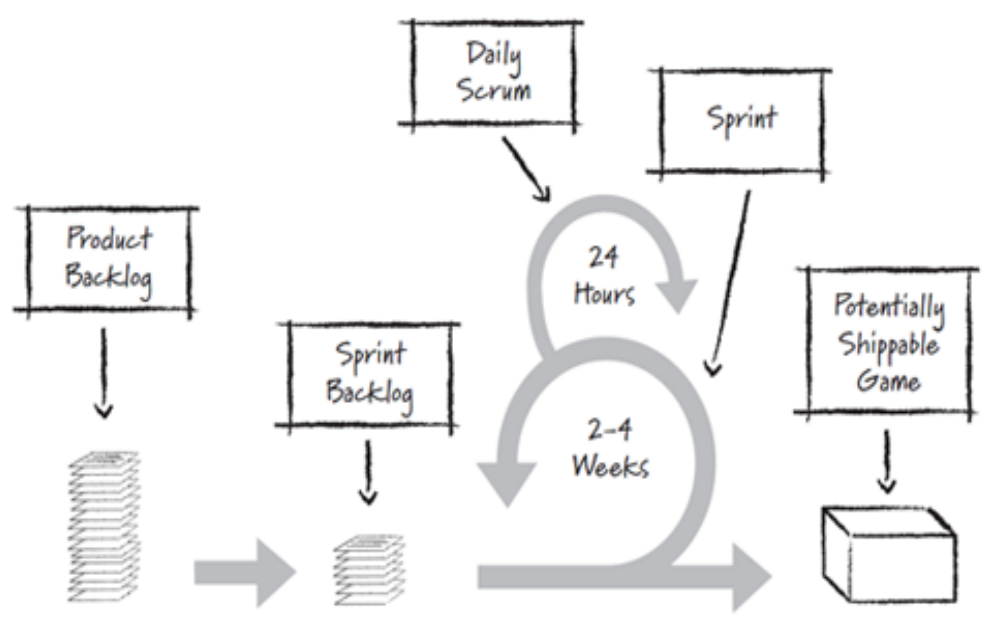

Gambar 1 Metode Scrum

\section{HASIL DAN PEMBAHASAN}

Aplikasi game My Name is Dug merupakan game untuk mobile dengan platform Android. Pada aplikasi game ini tidak ada urutan kegiatan yang harus dilakukan terlebih dahulu, karena aplikasi game ini bukan merupakan game yang memiliki jalan cerita. Aplikasi game ini memiliki empat mini games, yaitu Blow Up!, Tap The Drum, Remember It, dan Shake It. Blow Up! dan Tap The Drum dapat dimainkan dengan single player atau multiplayer mode sedangkan untuk Remember It dan Shake It hanya memiliki single player mode. Jika user memilih single player, maka user akan bermain game sendiri. Sedangkan jika user memilih multiplayer mode, maka user dapat bermain game bersama orang lain dengan mengaktifkan Bluetooth dan menghubungkan dengan device lain.

Selain user dapat memainkan minigames, user juga dapat melakukan beberapa aktivitas, seperti: (a) Melakukan Voice Recognition; user dapat melakukan voice recognition dengan menekan tombol record pada layar dan berbicara atau bersuara apa saja. Sistem akan mendeteksi suara dari user yang masuk dan akan mengulang perkataan atau suara tersebut. Tombol record yang digunakan untuk melakukan voice recognition bertujuan untuk mencegah terjadinya suara yang masuk secara terus menerus. Hal itu terjadi pada aplikasi seperti Talking Tom Cat dan Talking Ben. Oleh karena itu penggunaan sebuah tombol sangat penting untuk mengaktifkan atau menonaktifkan fungsi deteksi suara user, sehingga user tidak akan merasa terganggu dengan adanya voice recognition yang mendeteksi dan mengulang suara user setiap saat. (b) Mengatakan Voice Recognition "Dug” dan "Jump"; user dapat melihat perubahan animasi yang terjadi pada karakter anjing Dug dengan mengatakan kata "Dug” dan “Jump”. (c) SeeInfo Menu; user dapat melihat info dengan menekan tombol info pada layar. Setelah user menekan tombol info, maka akan muncul tampilan layar yang menampilkan dua buah tab, yaitu Help dan Status. Jika user memilih tab Help, maka akan muncul semua informasi mengenai bagaimana cara menjalankan aplikasi game My Name is Dug. Sedangkan jika user memilih tab Status, maka akan muncul informasi mengenai berapa banyak user menang dan kalah dalam permainan multiplayer mode dan waktu terbaiknya dalam memainkan game dengan single player mode.

Aplikasi game ini berdasarkan pada aplikasi game lain yang sudah pernah ada sebelumnya, yaitu Talking Ben dan Talking Tom Cat. Namun aplikasi game My Name is Dug ini tidak sama dengan aplikasi game tersebut. Hanya konsep dasarnya saja yang sama, yaitu sama-sama memiliki 
karakter hewan dan mendukung teknologi voice recognition. Pada aplikasi game My Name is Dug terdapat mini games yang dapat dimainkan oleh user dan dapat dihubungkan dengan perangkat lainnya menggunakan teknologi Bluetooth untuk bermain bersama dalam minigames itu dan saling berkompetisi untuk memenangkannya.

Tujuan dari aplikasi game ini adalah untuk menunjukkan teknologi voice recognition dan inter-devices connection dengan menggunakan teknologi Bluetooth.

Aplikasi game My Name is Dug memiliki empat mini games, yaitu Blow Up!,Tap The Drum, Remember It, and Shake It.

\section{Use Case Diagram}

Berikut adalah Use Case Diagram (Whitten and Bentley, 2007) untuk menggambarkan fungsionalitas aplikasi.

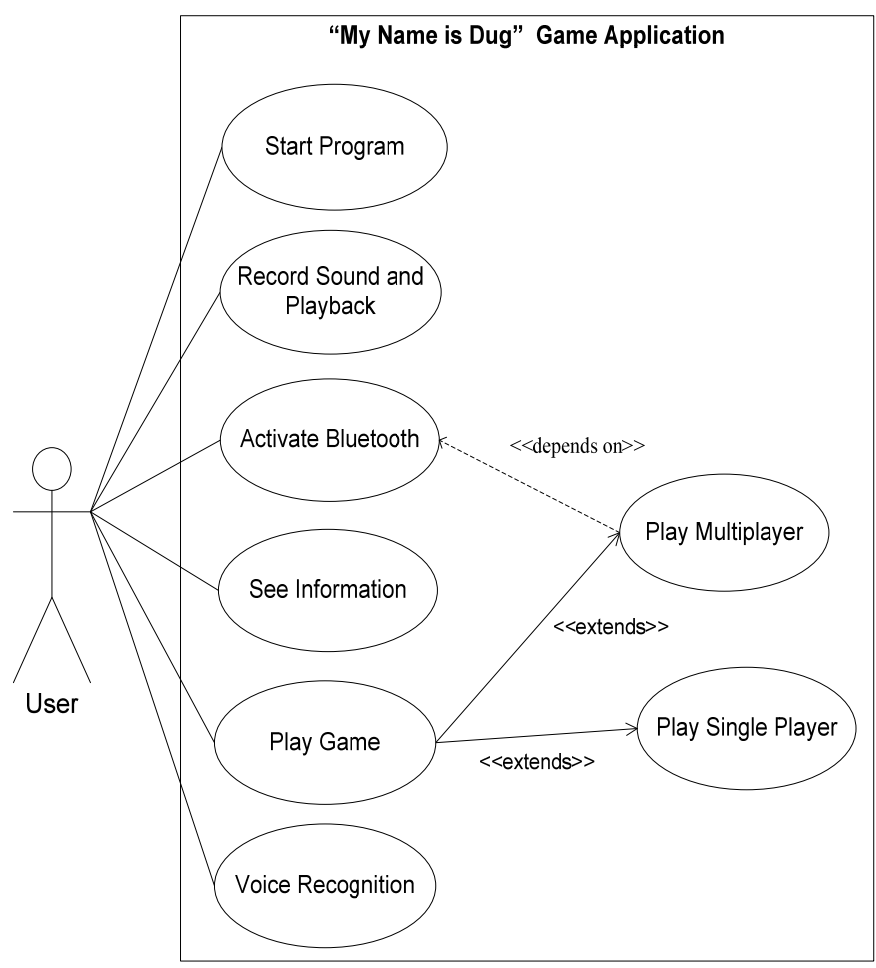

Gambar 2 Use Case Diagram

\section{Implementasi}

Untuk menggunakan aplikasi ini, spesifikasi mobile phone minimal yang harus adalah:

$\begin{array}{ll}\text { RAM } & : 278 \mathrm{MB} \\ \text { Internal Memory } & : 5 \mathrm{MB} \text { free } \\ \text { CPU } & : 800 \mathrm{MHz} \text { ARM } 11 \\ \text { Android } & : 2.2 \text { Froyo }\end{array}$


Sedangkan spesifikasi sistem mobile phone yang direkomendasikan adalah:

$\begin{array}{ll}\text { RAM } & : 512 \mathrm{MB} \\ \text { Internal Memory } & : 5 \mathrm{MB} \text { free } \\ \text { CPU } & : 1.4 \mathrm{GHz} \text { Scorpion } \\ \text { Android } & : 2.3 \text { Gingerbread }\end{array}$

\section{Evaluasi}

Evaluasi dilakukan berdasarkan Delapan Aturan Emas (Shneiderman and Plaisant, 2010) terdiri dari Konsistensi, Melayani Penggunaan yang Universal, Merancang Dialog untuk Menghasilkan Suatu Penutupan, Memberikan Penanganan Kesalahan yang Sederhana, Mudah Kembali ke Tindakan Sebelumnya, Internal Locus of Control, dan Mengurangi Beban Ingatan Jangka Pendek.

\section{Konsistensi}

Untuk menjaga kekonsistenan, aplikasi game My Name is Dug menggunakan jenis dan warna huruf yang sama untuk halaman konfirmasi serta tulisan pada button. Selain itu, untuk button yang digunakan pada saat memilih game, game mode, serta melihat status menggunakan button yang sama. Background untuk setiap menu memiliki tema yang hampir sama dan tidak jauh berbeda satu dengan yang lain.

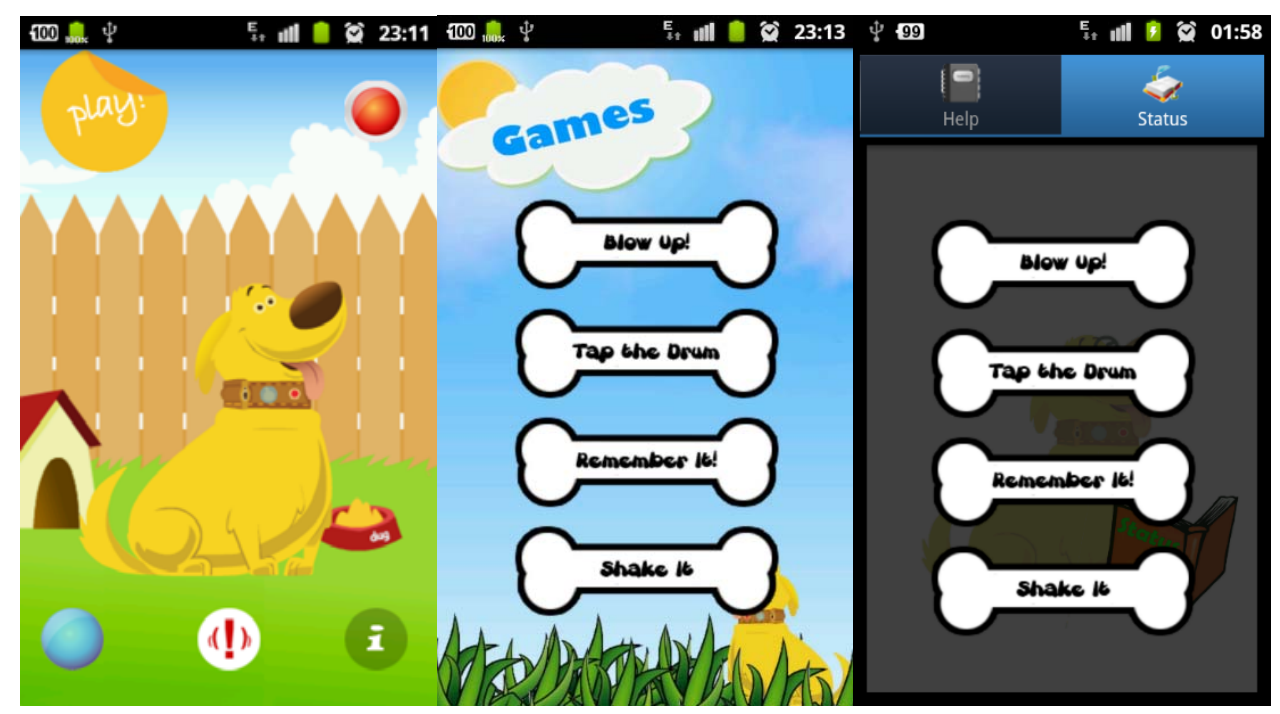

Gambar 3 Contoh konsistensi pada aplikasi game My Name is Dug

\section{Melayani Penggunaan yang Universal}

Di dalam aplikasi game My Name is Dug diberikan menu help bagi user yang menggunakan aplikasi game My Name is Dug untuk pertama kalinya, sehingga user mengerti fitur-fitur yang ada di dalam aplikasi game ini. Selain itu juga disediakan shortcut dengan menggunakan gambar yang sesuai dengan fiturnya untuk memudahkan user untuk memilih menu yang diinginkan. 

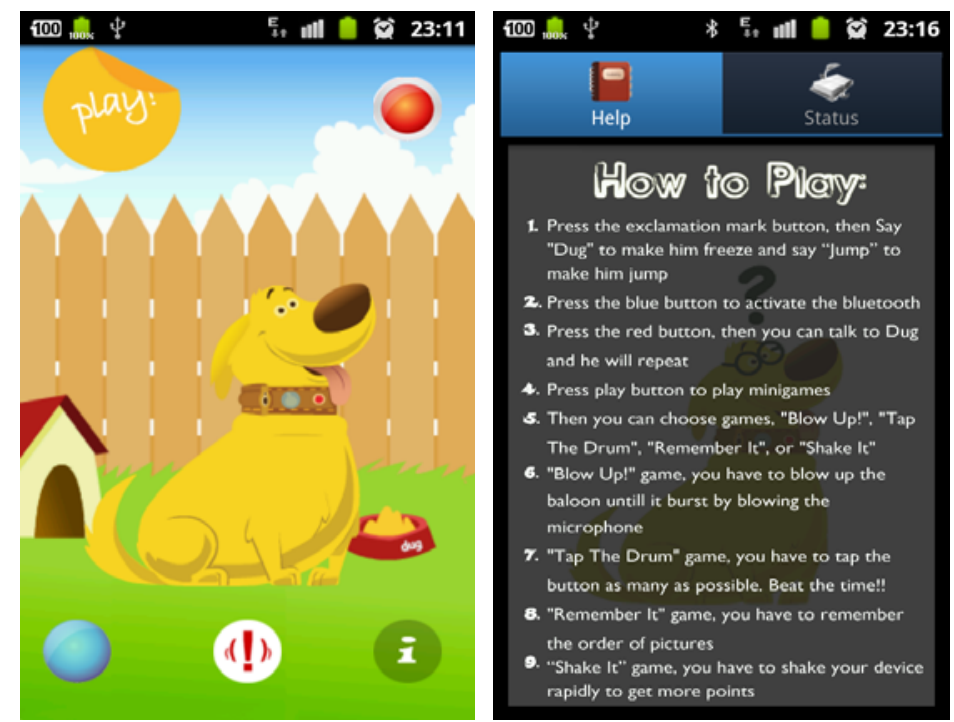

Gambar 4 Contoh melayani penggunaan yang universal pada aplikasi game My Name is Dug

\section{Memberikan Umpan Balik yang Informatif}

Di dalam aplikasi game My Name is Dug disediakan beberapa umpan balik sesuai dengan aktivitas yang dilakukan oleh user. Contohnya adalah ketika user berusaha mengaktifkan Bluetooth, maka akan ditampilkan kotak konfirmasi untuk mengaktifkan Bluetooth dan setelah itu akan ditampilkan status dari Bluetooth. Selain itu, ketika user mencoba untuk menyambungkan dengan device lain, maka akan ditampilkan apakah device berhasil tersambung atau tidak.

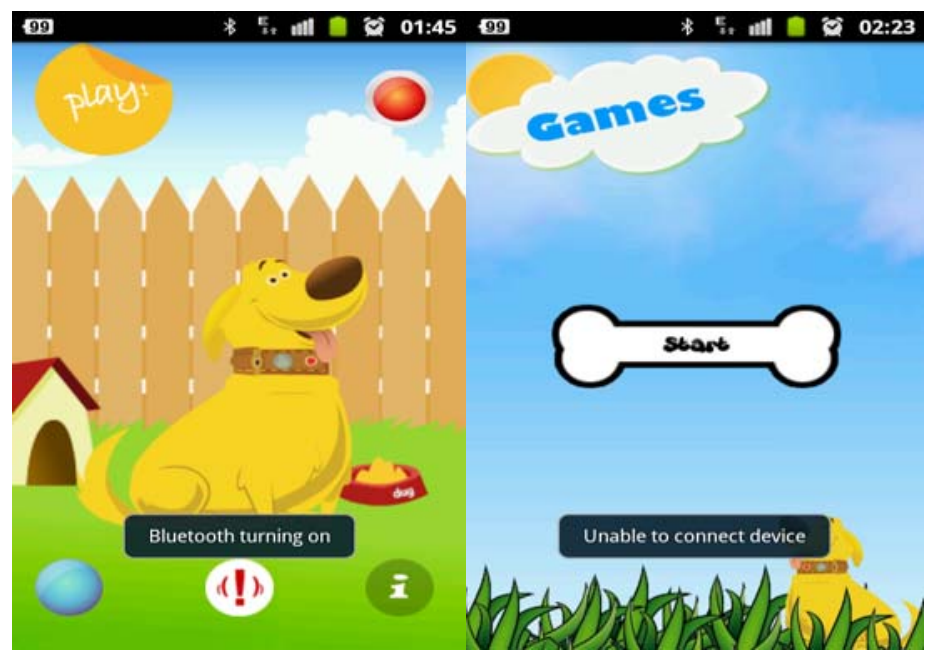

Gambar 5 Contoh umpan balik yang informatif pada aplikasi game My Name is Dug

\section{Merancang Dialog untuk Menghasilkan Suatu Penutupan}

Untuk setiap game yang sudah diselesaikan akan ditampilkan halaman konfirmasi yang berisikan nilai dan status dari user tersebut. Halaman ini akan menjadi penanda bahwa user telah berhasil menyelesaikan game tersebut. 


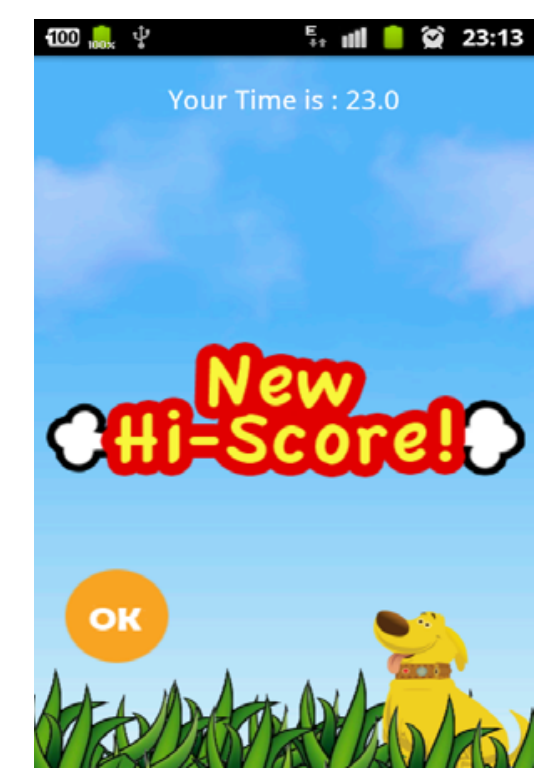

Gambar 6 Contoh Dialog untuk penutupan pada aplikasi game My Name is Dug

\section{Memberikan Penanganan Kesalahan yang Sederhana}

Di dalam multi player game, akan dimunculkan pesan error jika user lupa untuk menghubungkan dengan device yang lain. Hal ini untuk mencegah terjadinya error pada saat bermain multi player game jika device dari user belum terhubung dengan device lainnya.

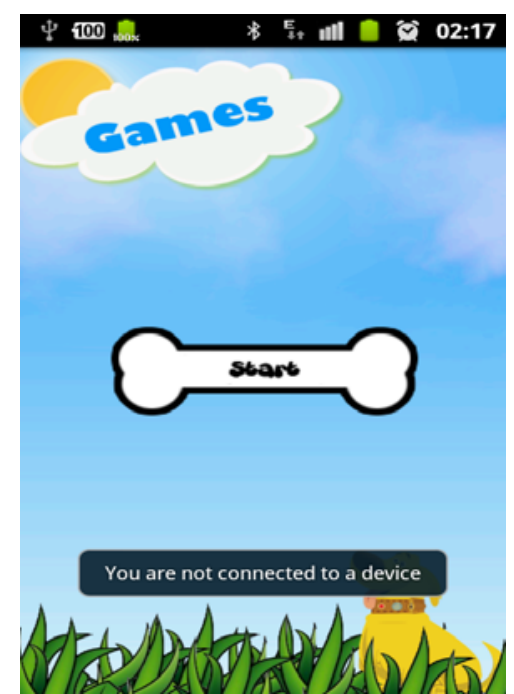

Gambar 7 Contoh penanganan kesalahan yang sederhana pada aplikasi game My Name is Dug

\section{Mudah Kembali ke Tindakan Sebelumnya}

Untuk memudahkan user kembali ke tindakan sebelumnya dengan mudah, aplikasi game My Name is Dug akan memunculkan halaman konfirmasi untuk aktifitas yang dianggap penting dan juga menyediakan tombol untuk kembali ke halaman sebelumnya. Contohnya adalah pada saat user mencoba untuk keluar dari permainan saat game sedang berjalan, akan dimunculkan halaman 
konfirmasi apakah user benar-benar ingin keluar dari permainan. Selain itu, pada saat pemilihan mode game akan disediakan tombol back untuk kembali ke menu sebelumnya, yaitu menu untuk memilih jenis permainan.

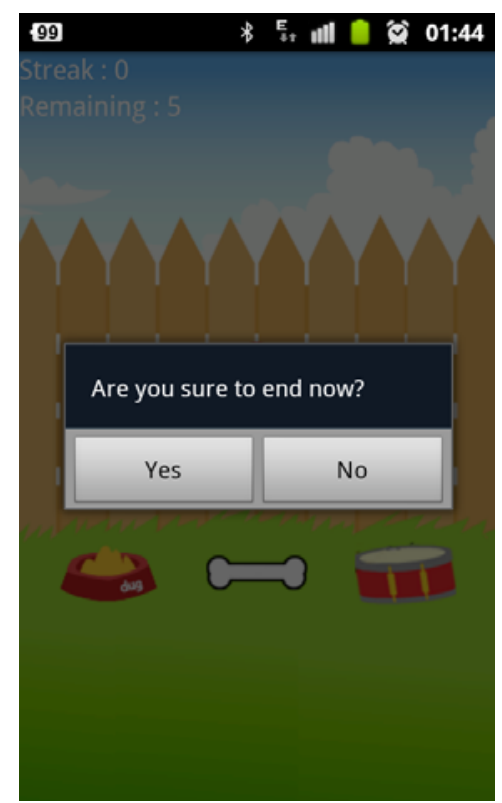

Gambar 8 Contoh mudah kembali ke tindakan yang sebelumnya pada aplikasi game My Name is Dug

\section{Internal Locus of Control}

Di dalam aplikasi game My Name is Dug, Bluetooth menjadi salah satu komponen utama, tetapi ketika membuka aplikasi game My Name is Dug ini user tidak dipaksa untuk mengaktifkan Bluetoothnya. Aplikasi tetap akan meminta konfirmasi dari user untuk mengaktifkan Bluetooth. Selain itu, user diberi wewenang penuh untuk memilih fitur yang hendak digunakan di dalam menu utama.
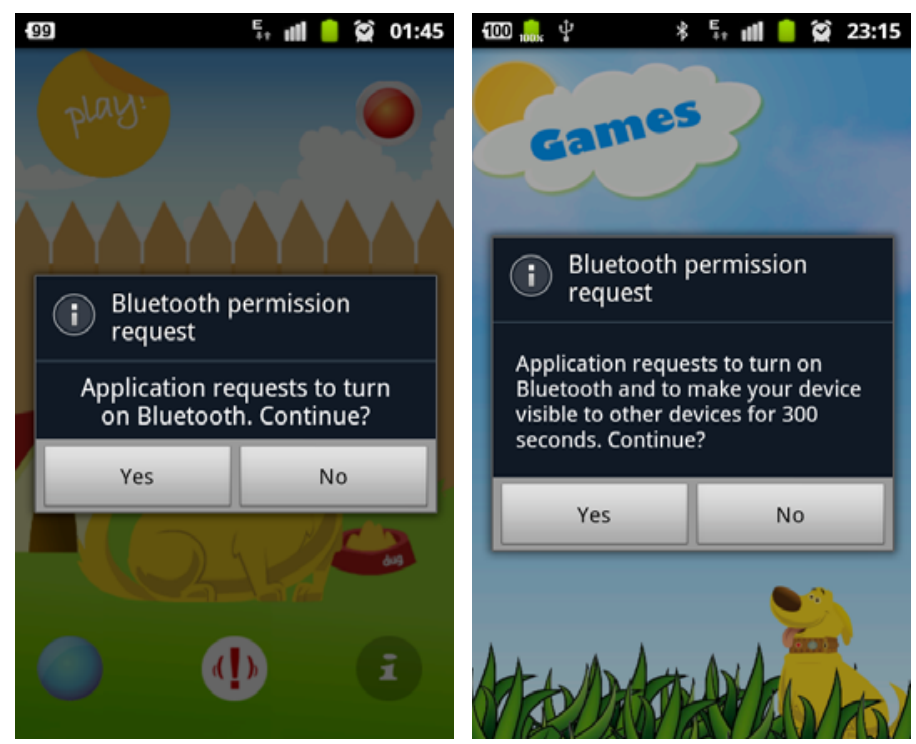

Gambar 8 Contoh internal locus of control pada aplikasi game My Name is Dug 


\section{Mengurangi Beban Ingatan Jangka Pendek}

Pada saat bermain game Remember It akan ditampilkan jumlah remaining dari jawaban yang harus dimasukkan oleh user. Hal ini bertujuan agar user tidak perlu mengingat sudah berapa banyak jawaban yang sudah user masukkan. Selain itu juga akan diberikan fasilitas status dimana user bisa melihat lagi status user dalam permainan dan tidak perlu mengingat status user.

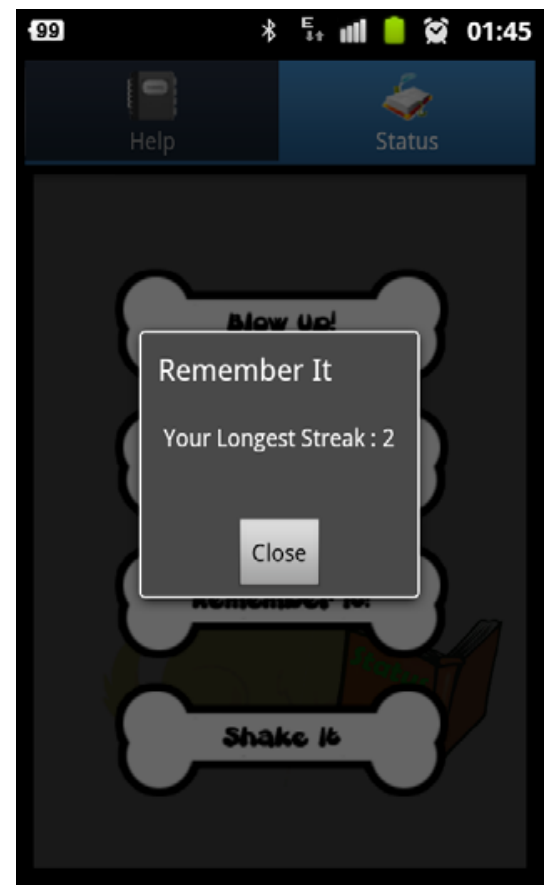

Gambar 9 Contoh mengurangi beban ingatan jangka pendek pada aplikasi game My Name is Dug

\section{SIMPULAN}

Kesimpulan yang dapat diambil dari penelitian ini adalah sebagai berikut: (1) Aplikasi My Name is Dug merupakan aplikasi game untuk mobile phone dengan sistem operasi Android 2.2, Java Language (Eclipse Java EE IDE version indigo release), Android SDK, dan Android API Level 10. (2) Aplikasi game ini menggunakan teknologi voice recognition sehingga user dapat bermain dengan karakter anjing Dug dan inter-devices connection menggunakan Bluetooth untuk bermain minigames dengan multiplayer mode. (3) Fitur yang ada dalam aplikasi game ini adalah merekam suara, bermain minigames baik single maupun multiplayer menggunakan koneksi Bluetooth, dan voice recognition untuk kata "Dug” dan “Jump”. (4) Minigames yang dikembangkan menggunakan beberapa teknologi diantaranya teknologi Bluetooth untuk mendukung multiplayer game, voice recognition untuk minigame Blow Up!, dan motion detection untuk minigame Shake It. (5) Berdasarkan pada hasil kuesioner yang telah dilakukan, maka dapat diketahui bahwa fitur-fitur yang ada di dalam aplikasi game My Name is Dug berjalan dengan baik dan menarik bagi user. 


\section{DAFTAR PUSTAKA}

Desai, C., Colaco, V. (2010). Development of a Personalized Integrated Voice. International Conference and Workshop on Emerging Trends in Technology, 134-137.

Gartner. (2011). Gartner Says Android to Command Nearly Half of Worldwide Smartphone Operating System Market by Year-End 2012. diakses February 22, 2012, dari http://www.gartner.com/newsroom/id/1622614

Keith, C. (2010). Agile game development with Scrum (1st ed.). Boston: Pearson Education.

Shneiderman, B., Plaisant, C. (2010). Designing the User Interface ( $5^{\text {th }}$ ed.). Boston: Pearson

Whitten, J. L., Bentley, L. D. (2007). System Analysis and Design Methods (7th ed.). New York: McGraw-Hill/Irwin. 